\title{
PENGARUH PENGENDALIAN INTERN PERKREDITAN TERHADAP KREDIT BERMASALAH PADA PT. BANK RAKYAT INDONESIA (PERSERO) TBK, CABANG TELUK BETUNG
}

\author{
Haninun
}

\begin{abstract}
Development bank in Lampung province experienced a fairly rapid developments, this rapid growth led to increased competition among banks in seizing the customer to raise funds as much as possible from the community. Funds raised are then arranged in order to provide benefits for banks, in other words, the funds channeled back into the community in the form of credit. Bank as a form of business entity, of course activities undertaken expect profit. It is a natural thing, but in the implementation of the provision of credit, in addition to fulfilling the objectives of banking business motive profile bank also should serve as an agent of development, meaning that the bank should be able to guide the debiturny, so that the loan has been disbursed to meet the original target. To maintain the position of overseeing monetary and credit can be done by setting the direction of credit such as credit type setting priorities as has been done by PT. Bank Rakyat Indonesia. (Persero) Tbk. Teluk Betung branch.

This type of research in the form of descriptive research and associative. Descriptive research conducted to get an overview of the variables used in this study, whereas associative research is used to examine the relationship between internal control or influence of the level of over due loans credit by using statistical test.
\end{abstract}

Keywords: Internal control, Non-performing Loans, Agent of development

\section{PENDAHULUAN}

\section{Latar Belakang}

Sektor perbankan merupakan salah satu unsur dalam pembangunan nasional dan memiliki peranan penting dalam memperlancar jalannya pembangunan nasional. Fungsi utama sektor perbankan adalah menghimpun dana dari masyarakat dan menyalurkannya kembali kepada masyarakat dalam bentuk kredit. Disamping itu juga perbankan berfungsi dalam memperlancar jalannya transaksi perdagangan, mempermudah proses pengiriman uang (jasa transfer) dan sebagainya.

Dunia perbankan mengalami perkembangan yang sangat pesat sebagai akibat di keluarkannya deregulasi disektor perbankan oleh pemerintah yaitu penyerdehanaan undangundang perbankan seperti suku bunga deposito, dan pinjaman (kredit). Melalui deregulasi ini, dunia perbankan diberi kemudahan-kemudahan dan peluang untuk mengembangkan usahanya. Bank-bank baru dan kantor cabang banyak bermunculan, tersebar diseluruh wilayah Indonesia yang dianggap cukup potensial bagi perkembangan bank. Deregulasi sektor perbankan yang dikeluarkan oleh pemerintah juga menyebabkan bank berlomba-lomba 
untuk memberikan pelayanan yang terbaik untuk nasabahnya, menciptakan produk yang memiliki daya saing tinggi dan memberikan fasilitas yang terbaik untuk nasabahnya.

Perkembangan bank di propinsi Lampung mengalami perkembang yang cukup pesat, perkembangan yang pesat ini menyebabkan meningkatnya persaingan antar bank dalam merebut nasabah guna menghimpun dana yang sebesar-besarnya dari masyarakat. Dana yang dihimpun ini kemudian diusahakan agar dapat memberikan keuntungan bagi bank, dengan kata lain dana disalurkan kembali ke masyarakat dalam bentuk kredit. Bank sebagai salah satu bentuk badan usaha, tentu saja aktivitas yang dilakukan mengharapkan adanya keuntungan. Hal tersebut merupakan sesuatu yang wajar, tetapi dalam pelaksanaan pemberian kredit, disamping memenuhi tujuan usaha perbankan yaitu profil motive bank juga harus mampu sebagai agent of development, artinya bank harus mampu melakukan pembinaan terhadap debiturny, sehingga kredit yang telah disalurkan tersebut dapat memenuhi sasaran semula. Untuk menjaga posisi moneter dan mengawasi kredit dapat dilakukan melalui pengaturan arah pemberian kredit misalnya pengaturan jenis kredit yang prioritas seperti yang telah dilakukan oleh PT. Bank Rakyat Indonesia. (Persero) Tbk. Cabang Teluk Betung.

Kredit merupakan kegiatan usaha perbankan yang mempunyai resiko tinggi, karena kredit merupakan asset bank yang ada di pihak luar bank (debitur). Oleh karena sudah sepantasnya apabila bank memberikan perhatian yang besar dalam melaksanakan kegiatanya tesebut, yaitu dengan menetapkan kebijakan-kebijakan kredit yang tidak terlepas dari likuiditas, solvabilitas, dan rentabilitas, disamping itu juga bank harus mampu mengembalikan dana yang telah dihimpunnya berupa pokok dan bunga. Dalam pemberian kredit sangatlah penting bagi bank untuk mempertimbangkan beberapa faktor baik yang berasal dari intern maupun faktor ektern, faktor intern meliputi kebijakan dalam prosedur pemberian kredit, sedangkan faktor ekstern meliputi kemampuan nasabah dalam membayar cicilan dan pertumbuhan ekonomi.

Dari uraian singkat diatas tampak bahwa, betapapun kecilnya, selama masa hidupnya bank tidak dapat terlepas sama sekali dari resiko menghadapi kasus kredit bermasalah. Oleh karena itu dalam menyusun strategi menanamkan dana yang dikuasai seyogyanya bank tidak terpaku pada usaha menghindari kredit bermasalah, melainkan berusaha menekan resiko munculnya kasus itu serendah mungkin. Secara garis besar dapat dikatakan bahwa usaha menekan resiko munculnya kredit bermasalah dapat dilakukan dengan jalan menjaga mutu kredit yang disalurkan.

Dalam penyaluran kredit peranan pengendalian intern menjadi sangat penting, dengan penerapan sistem pengendalian intern yang memadai, maka akan dapat menjamin kelayakan operasi yang dijalankan. Pengendalian intern ini dimulai dari ditaatinya prosedur pemberian kredit, sumber daya manusia yang cukup berkualitas dan pengawasan yang berkelanjutan setelah kredit tersebut diberikan, sehingga resiko akan kemungkinan kerugian dimasa mendatang dapat diperkecil.

Untuk lebih fokusnya, penulis membatasi ruang lingkup pembahasan hanya pada Unit Bisnis Mikro yang ada pada PT. Bank Rakyat Indonesia (Persero) Cabang Teluk Betung yang dikelola oleh beberapa kantor unit.

\section{Identifikasi Masalah}

Pada dasarnya kegiatan perkreditan harus sesuai dengan ketentuan sistem dan prosedur pemberian kredit dan berpedoman pada prinsip kehati-hatian, namun kenyataannya dijumpai banyak kredit bermasalah yang ditunjukkan angka tunggakan kredit berikut ini. 


\begin{tabular}{|c|c|c|c|c|c|c|}
\hline \multirow{2}{*}{ UNIT } & \multicolumn{2}{|c|}{2003} & \multicolumn{2}{c|}{2004} & \multicolumn{2}{c|}{2005} \\
\cline { 2 - 7 } & $\begin{array}{c}\text { Sem I } \\
(\mathbf{R p})\end{array}$ & $\begin{array}{c}\text { Sem II } \\
(\mathbf{R p})\end{array}$ & $\begin{array}{c}\text { Sem I } \\
(\mathbf{R p})\end{array}$ & $\begin{array}{c}\text { Sem II } \\
(\mathbf{R p})\end{array}$ & $\begin{array}{c}\text { Sem I } \\
(\mathbf{R p})\end{array}$ & $\begin{array}{c}\text { SemII } \\
(\mathbf{R p})\end{array}$ \\
\hline I & 6.760 .169 & 6.779 .705 & 6.878 .641 & 6.894 .694 & 6.839 .801 & 6.830 .047 \\
\hline II & 2.158 .338 & 2.152 .143 & 2.137 .929 & 2.182 .526 & 2.139 .658 & 2.173 .756 \\
\hline III & 5.593 .071 & 5.614 .518 & 5.855 .658 & 6.006 .405 & 6.109 .033 & 5.905 .310 \\
\hline IV & 2.045 .528 & 2.081 .976 & 2.173 .028 & 2.187 .940 & 2.211 .169 & 2.195 .776 \\
\hline V & 1.871 .534 & 2.008 .657 & 2.119 .452 & 2.249 .872 & 2.328 .101 & 2.276 .949 \\
\hline VI & 2.282 .717 & 2.441 .956 & 2.513 .392 & 2.730 .623 & 2.823 .810 & 2.766 .645 \\
\hline VII & 2.354 .036 & 2.375 .648 & 2.599 .017 & 2.683 .872 & 2.776 .594 & 2.797 .941 \\
\hline VIII & 4.137 .359 & 4.221 .382 & 1.412 .665 & 4.488 .039 & 4.493 .317 & 4.591 .636 \\
\hline IX & 1.580 .153 & 1.602 .205 & 1.661 .771 & 1.859 .918 & 1.678 .080 & 1.625 .794 \\
\hline X & 4.315 .051 & 4.203 .671 & 4.194 .927 & 4.368 .385 & 4.465 .240 & 4.330 .442 \\
\hline XI & 3.125 .790 & 3.113 .676 & 3.125 .501 & 3.203 .370 & 3.155 .553 & 3.077 .521 \\
\hline XII & 2.259 .841 & 2.257 .844 & 2.432 .771 & 2.567 .590 & 2.608 .507 & 2.498 .342 \\
\hline & 38.483 .587 & 38.853 .381 & 40.104 .752 & 41.223 .234 & 41.628 .813 & 41.070 .159 \\
\hline
\end{tabular}

Sumber : PT. BRI Cab. Teluk Betung, Th 2006 (data diolah)

Tabel 1.2.2. Daftar kredit bermasalah pada PT. Bri-unit cabang Teluk Betung Th 2003-2005

\begin{tabular}{|l|c|c|c|c|c|c|}
\hline \multirow{2}{*}{ Keterangan } & \multicolumn{2}{|c|}{$\mathbf{2 0 0 3}$} & \multicolumn{2}{c|}{2004} & \multicolumn{2}{c|}{2005} \\
\cline { 2 - 7 } & $\begin{array}{c}\text { Sem I } \\
(\mathbf{R p})\end{array}$ & $\begin{array}{c}\text { Sem II } \\
(\mathbf{R p})\end{array}$ & $\begin{array}{c}\text { Sem I } \\
(\mathbf{R p})\end{array}$ & $\begin{array}{c}\text { Sem II } \\
(\mathbf{R p})\end{array}$ & $\begin{array}{c}\text { Sem I } \\
(\mathbf{R p})\end{array}$ & $\begin{array}{c}\text { Sem II } \\
(\mathbf{R p})\end{array}$ \\
\hline $\begin{array}{l}\text { 1.Kredit Dalam } \\
\text { Perhatian } \\
\text { Khusus }\end{array}$ & 1.908 .420 & 1.924 .109 & 1.769 .466 & 1.956 .672 & 3.067 .988 & 2.479 .604 \\
\hline $\begin{array}{l}\text { 2.Kredit Kurang } \\
\text { Lancar }\end{array}$ & 719.074 & 754.578 & 777.687 & 814.649 & 909.554 & 1.807 .319 \\
\hline $\begin{array}{l}\text { 3.Kredit } \\
\text { Diragukan }\end{array}$ & 491.505 & 487.723 & 482.585 & 476.610 & 495.940 & 578.483 \\
\hline 4.Kredit Macet & 231.671 & 332.484 & 341.601 & 381.856 & 426.567 & 496.480 \\
\hline TOTAL & 3.350 .670 & 3.498 .894 & 3.671 .339 & 3.629 .787 & 4.473 .482 & 5.361 .886 \\
\hline
\end{tabular}

Sumber : PT. BRI Cab. Teluk Betung, Th 2006 (data diolah)

\section{Penjelasan:}

1. Kredit Dalam Perhatian Khusus Menunggak 1 sampai dengan 90 hari

2. Kredit Kurang Lancar

Menunggak lebih dari 90 hari, sampai dengan 120 hari

3. Kredit Diragukan

Menunggak lebih dari 120 hari, sampai dengan 180 hari

4. Kredit Macet

Menunggak lebih dari 180 hari, sampai dengan 270 hari 
Tabel 1.2.2. Daftar kredit bermasalah pada PT. Bri-Unit cabang Teluk Betung Th 2003-2005

\begin{tabular}{|c|c|c|c|c|}
\hline \multirow{2}{*}{ SEMESTER } & \multicolumn{2}{|c|}{ KUPEDES } & \multicolumn{2}{c|}{ KREDIT BERMASALAH } \\
\cline { 2 - 5 } & $\mathbf{( R p )}$ & $\mathbf{\%}$ & $\mathbf{( R p )}$ & \% \\
\hline 2003 (I) & 38.483 .587 & - & 3.350 .670 & - \\
\hline 2003 (II) & 38.853 .381 & 0,96 & 3.498 .894 & 4,40 \\
\hline 2004 (I) & 40.104 .752 & 3,20 & 3.671 .339 & 4,90 \\
\hline 2004 (II) & 41.223 .234 & 2,70 & 3.629 .787 & $-1,13$ \\
\hline 2005 (I) & 41.628 .813 & 0,98 & 4.473 .482 & 23,00 \\
\hline 2005 (II) & 41.070 .159 & $-1,34$ & 5.361 .886 & 19,00 \\
\hline
\end{tabular}

\section{Perumusan Masalah}

Atas dasar masalah diatas maka dirumuskan permasalahan sbb:

"Seberapa Besar Pengaruh Pengendalian Intern Perkreditan Terhadap Kredit Bermasalah Pada PT. Bank Rakyat Indonesia- Unit Cabang Teluk Betung?" Tujuan Penelitian

1. Untuk mengetahui penerapan pengendalian intern terhadap kredit bermasalah pada PT. Bank Rakyat Indonesia-Unit Cabang Teluk Betung.

2. Untuk mengetahui pengaruh pengendalian intern terhadap kredit bermasalah.

\section{Kegunaan Penelitian}

Sebagai sumbangan pemikiran pada PT. Bank Rakyat Indonesia-Unit Cabang Teluk Betung tentang pentingnya peranan pengendalian intern.

\section{Kerangka Teoritik Dan Hipotesis}

\section{Sistem Pengendalian Intern}

Pengendalian merupakan salah satu fungsi manajemen. Dengan demikian, maka sudah menjadi kewajiban bagi manajemen untuk menciptakan suatu sistem pengawasan dari perusahaan dengan cara seefektif dan seefisien mungkin. Salah satu pengawasan tersebut adalah apa yang disebut dengan pengendalian intrn.

Kebutuhan terhadap pengendalian intern sangat dirasakan oleh manajemen pada suatu keadaan dimana pimpinan karena keterbatasannya tidak sanggup lagi secara langsung mengendalikan segala kegiatan yang terjadi dalam perusahaan. Keadaan seperti ini biasanya disebabkan karena lingkup perusahaan sebagai suatu kesatuan ekonomi sudah meluas sedemikian rupa, sehingga struktur organisasi perusahaan menjadi semakin kompleks.

Pengendalian Intern dapat diartikan sebagai sistem, struktur atau proses yang dijalankan oleh dewan direksi perusahaan, manajemen dan personel lain yang dimaksudkan untuk menyediakan jaminan tentang pencapaian tujuan pengendalian melalui pengelompokan keevektivan dan efisiensi operasi, reabilitas pelaporan keuangan, kesesuaian dengan hukum dan peraturan. (M. Fakhri Husein, 2003 : 120)

Pengendalian intern atau pengawasan intern dapat dibedakan atas dua bagian yaitu dalam arti sempit dan dalam arti luas. Dalam arti sempit, pengendalian intern adalah metode dan pengukuran yang dibentuk dalam sistem akuntansi untuk mengecek ketepatan pencatatan dalam penjumlahan baik penjumlahan mendatar maupun penjumlahan menurun dan pengamanan harta kekayaan perusahaan yang disebut juga internal check. Sedangkan pengertian pengendalian intern dalam arti luas mencangkup pengendalian baik bersifat akuntansi maupun administrasinya artinya pengendalian intern tidak hanya meliputi 
pekerjaan pengecekan tetapi semua alat-alat yang dipergumakan manajemen untuk mengadakan pengawasan.

Menurut AICPA (American Institute of Certified Public Accountant) definisi pengendalian intern dalam arti luas adalah sebagai berikut: "Pengendalian intern meliputi struktur organisasi dan semua cara-cara serta alat-alat yang dikoordinasikan yang digunakan di dalam perusahaan dengan tujuan menjaga keamanan harta milik perusahaan, memeriksa ketelitian dan kebenaran data akuntansi, memajukan efisiensi di dalam operasi dan membantu menjaga dipatuhinya kebijaksanaan manajemen yang telah ditetapkan terlebih dahulu". (Zaki Baridwan, 1993 : 13)

Pengertian menurut AICPA tersebut tidak hanya mencangkup kegiatan/aktivitas akuntansi keuangan, tetapi juga meluas sampai pada setiap aspek perusahaan. Dari pengertian diatas, pengendalian intern dalam arti luas mencangkup pengendalian intern yang bersifat accounting control atau financial control (pengendalian akuntansi)maupun administrative control (pengendalian administrasi). Seperti yang dilakukan oleh Ruchyat Kosasih (1982 : 102) dalam bukunya "Auditing Prinsip dan Prosedur sebagai berikut : Pengendalian akuntansi meliputi rencana organisasi dan semua metode serta prosedur yang terutama menyangkut dan berhubungan langsung dengan pengamanan kekayaan dan dapat dipercayainya catatan keuangan".

"Pengendalian administrasi meliputi rencana organisasi dan semua metode serta prosedur yang terutama mengenai efisiensi operasi dan ketaatan terhadap kebijaksanaan pimpinan dan biasanya berhubungan secara tidak langsung dengan catatan keuangan”.

Menurut Mulyadi dalam bukunya Sistem Akuntansi mendefinisikan system pengendalian intern sebagai berikut: "Sistem Pengendalian Intern meliputi struktur organisasi, metode dan ukuran-ukuran yang dikoordinasikan untuk menjaga kekayaan organisasi, mengecek ketelitian, dan keandalan data akuntansi, mendorong efisiensi, dan mendorong dipatuhinya kebijakan manajemen" (2001 : 162).

Sedangkan menurut George H. Bodnar dan William . hopwood, struktur pengendalian intern terdiri dari kebijakan-kebijakan dan prosedur-prosedur untuk menyediakan jaminan yang memadai bahwa tujuan-tujuan perusahaan dapat dicapai. (Amir Abadi Jusuf 2000 : 174).

Berdasarkan pendapat-pendapat tersebut dapat disimpulkan bahwa Pengendalian Intern adalah rancangan atau rencana organisasi, semua metode dan prosedur serta tindakan atau langkah yang terkoordinir yang digunakan oleh perusahaan_perusahaan untuk:

- Melindungi harta kekayaan perusahaan dari pencurian, penggelapan, atau hal-hal lain yang tidak diinginkan.

- Mengecek ketelitian data akuntansi dan mendorong ditaatinya kebijaksanaan manajemen yang telah ditentukan.

Pengendalian intern dapat dibedakan menjadi dua yaitu: Pengendalian akuntansi dan pengendalian administratif.

1. Pengendalian akuntansi (Accounting Control), meliputi : rencana organisasi, prosedurprosedur dan catatan-catatan yang berhubungan langsung dengan pengamanan aktiva perusahaan dan dapat dipercayainya catatan keuangan dan karenanya disusun sedemikian rupa untuk meyakinkan bahwa:

a. Transaksi dilakukan sesuai dengan persetujuan pihak baik yang bersifat umum maupun bersifat khusus.

b. Transaksi dicatat sedemikian rupa, sehingga memungkinkan dibuat ikhtisar-ikhtisar keuangan yang sesuai dengan tujuan-tujuan dan menekankan pada tanggungjawab perusahaan. 
c. Penguasaan atas aktiva perusahaan diberikan hanya dengan persetujuan atau wewenang.

d. Jumlah aktiva perusahaan seperti yang tercantum dalam catatan yang tepat dan bila terjadi perbedaan diambil tindakan yang wajar.

2. Pengendalian Administratif (Administrative Control), meliputi : rencana organisasi, semua metode dan prosedur terutama yang berhubungan langsung dengan setiap transaksi serta keadaan dari catatan keuangan perusahaan, sehingga diharapkan keamanan harta perusahaan dapat terjamin.

Kedua pengendalian diatas tidak secara tegas terpisah antara satu dengan yang lainnya, sebab beberapa prosedur dan catatan yang tercakup dalam pengendalian akuntansi dapat juga tercakup dalam pengendalian administratif.

\section{Tujuan Pengendalian Intern}

Alasan perusahaan perlu memiliki suatu pengendalian intern adalah untuk menjamin tujuan yang telah ditetapkan oleh pemilik atau manajemen secara efektif dan efisien. Berdasarkan pengertian pengendalian intern seperti yang dikemukakan tersebut maka secara garis besar dapat dirumuskan adanya empat tujuan pengendalian intern yaitu sebagai berikut :

1. Menjaga keamanan harta milik suatu perusahaan atau organisasi.

2. Memeriksa ketelitian dan kebenaran data akuntansi.

3. Memajukan efisiensi dalam operasi.

4. Membantu menjaga dipatuhinya semua kebijakan, peraturan dan prosedur pelaksanaan kegiatan yang telah ditetapkan manajemen.

Dari keempat tujuan pengendalian intern diatas dapat diuraikan sebagai berikut:

1. Menjaga keamanan harta milik suatu perusahaan atau organisasi

Barang-barang atau harta milik perusahaan biasanya hilang karena dicuri, disalahgunakan, rusak karena kecelakaan atau musibah, dan lain-lain sebab yang pada dasarnya berakibat kerugian bagi perusahaan, kecuali ada pengawasan yang memadai.

Hal yang sama bisa terjadi terhadap kekayaan perusahaan yang berupa hak seperti misalnya piutang dagang, dokumen-dokumen, dan catatan-catatan yang sangat berharga bagi perusahaan.

2. Memeriksa ketelitian dan kebenaran data akuntansi

Manajemen memerlukan informasi yang teliti, dapat dipercaya kebenarannya, dan tepat pada waktunya untuk mengelola kegiatan-kegiatan perusahaan. Terdapat banyak sekali tipe dan jenis informasi yang dibutuhkan oleh manajemen untuk dipakai sebagai dasar dalam membuat keputusan-keputusan penting yang menyangkut kegiatan dalam perusahaan.

3. Manajemen efisiensi dalam operasi Mekanisme pengendalian intern yang diasosiasikan dengan para personel dan kegiatannya, dimaksudkan untuk mencegah atau menghindar terjadinya berbagai peristiwa dan keadaan yang berakibat timbulnya inefisiensi operasi perusahaan, kelalaian, pemborosan dalam menggunakan sumber-sumber ekonomi.

4. Membantu menjaga dipatuhinya semua kebijakan, peraturan dan prosedur pelaksanaan kegiatan yang telah ditetapkan manajemen Kebijakan, peraturan dan prosedur-prosedur pelaksanaan kegiatan itu ditetapkan oleh manajemen sebagai alat untuk mencapai tujuan yang telah ditetapkan. Pengendalian intern beserta mekanismenya diciptakan untuk menjamin bahwa semua kebijakan, peraturan, prosedur-prosedur tersebut selalu dipatuhi oleh para karyawan. 


\section{Unsur-unsur Pengendalian Intern}

Menurut Arens dan Loebbbecke dalam buku Auditing, Struktur Pengendalian Intern mencangkup lima kategori dasar kebijakan dan prosedur yang dirancang dan digunakan oleh manajemen atau memberikan keyakinan memadai bahwa tujuan pengendalian dapat dipenuhi. Adapun kelima unsur tersebut sebagai berikut:

- Lingkungan pengendalian

- Penetapan resiko manajemen

- Sistem informasi dan komunikasi akuntansi

- Aktifitas pengendalian

- Pemantau

(Jusuf 1997:261)

Kelima unsur diatas disederhanakan oleh Mulyadi dalam bukunya Sistem Akuntansi, Unsur pokok Sistem Pengendalian Intern adalah:

1. Struktur Organisasi yang memisahkan tanggung jawab fungsional secara tegas.

2. Sistem Wewenang dan Prosedur pencatatan yang memberikan perlindungan yang cukup terhadap kekayaan, utang, pendapatan dan biaya.

3. Praktek yang sehat dalam melaksanakan tugas dan fungsi setiap unit organisasi.

4. Karyawan yang mutunya sesuai dengan tanggung jawabnya. (2001 : 164).

\section{Ketentuan Umum Pemberian Kredit.}

\section{Pengertian Kredit}

Kata kredit berasal dari Yunani "credere" yang berarti "kepercayaan" atau dalam bahasa latin "Creditum" yang berarti "kepercayaan akan kebenaran" dalam hal ini dasar dari kredit adalah kepercayaan.

Pengertian kredit menurut Undang-undang Pokok Perbankan No. 7 Tahun 1992: "Kredit adalah penyediaan uang atau tagihan yang dapat disamakan dengan itu berdasarkan persetujuan atau kesepakatan pinjam meminjam antara Bank dengan pihak lain yang mewajibkan pihak peminjam untuk melunasi hutangnya setelah jangka waktu tertentu dengan jumlah bunga, imbalan, hasil keuntungan”. (O.P. Simorangkir, 2004 : 100)

Sedangkan pengertian kredit secara umum adalah pemberian prestasi oleh suatu pihak kepada pihak lain dan prestasi itu akan dikembalikan lagi pada suatu masa tertentu yang akan datang disertai suatu kontra prestasi berupa bunga.

\section{Tujuan Pemberian Kredit}

Tujuan pemberian kredit khususnya kredit yang diberikan oleh bank pemerintah sebagai agent of development, adalah sbb:

1. Turut menyukseskan program pemerintah dibidang ekonomi dan pembangunan.

2. Meningkatkan aktivitas perusahaan agar dapat menjalankan fungsinya guna menjamin kebutuhan masyarakat memperoleh laba agar kelangsungan hidup perusahaan terjamin dan dapat memperluas usahanya.

Dari tujuan tersebut terlihat adanya kepentingan yang seimbang antara kepentingan masyarakat (rakyat) dan kepentingan pemilik modal.

Fungsi kredit perbankan dalam kehidupan perekonomian dan perdagangan antara lain sebagai berikut:

1. Kredit pada hakekatnya dapat meningkatkan daya guna uang.

2. Kredit dapat meningkatkan peredaran lalu lintas uang.

3. Kredit dapat meningkatkan daya guna dan peredaran barang. 
4. Kredit merupakan salah satu alat stabilitas ekonomi.

5. Kredit dapat meningkatkan kegairahan berusaha.

6. Kredit dapat meningkatkan pemerataan pendapatan.

7. Kredit merupakan alat untuk meningkatkan hubungan internasional (Simorangkir, 2004 : 103)

\section{Jenis-Jenis Kredit}

- Kredit Modal Kerja (KMK)

Kredit yang diberikan untuk keperluan pembiyaan modal kerja dengan jangka waktu pada umumnya 1 tahun.

- Kredit Investasi (KI)

Kredit yang diberikan untuk keperluan pembiyaan barang modal seperti pembangunan gedung, instalasi, perkebunan dan sebagainya, dengan jangka waktu diatas 1 tahun.

- Kredit Konsumsi (KK)

Kredit yang diberikan untuk keperluan konsumsi antara lain kredit pegawai, kendaraan bermotor, alat-alat rumah tangga, KPR dan sebagainya dengan jangka waktu bervariasi.

\section{Pertimbangan Pemberian Kredit.}

Faktor-faktor yang mempengaruhi bank dalam menilai sipemohon kredit adalah sebagai berikut:

1. Karakter (character), yaitu tabiat serta kemauan si pemohon untuk memenuhi kewajiban-kewajiban yang telah dijanjikan. Dalam hal ini yang diteliti adalah: sifat, kebiasaan, kepribadian, cara hidup dan keadaan keluarga.

2. Kemampuan (capability), yaitu kesanggupan sipemohon untuk mengembalikan pinjaman dan untuk memenuhi kewajiban-kewajiban lainnya. Adapun kemampuan sipemohon tergantung pada kecakapan, sifat, keadaan perusahaan dan situasi perekonomian. Dalam hal kemampuan biasanya bank meneliti tentang pengalaman bidang usaha, penyesuaian diri dibidang bisnis, dan penyesuaian dengan perkembangan kemajuan teknologi.

3. Modal (capital), penyelidikan terhadap modal ditinjau dari segi besar kecilnya modal yang ditanam, cukupkah modal yang tersedia, sehingga diharapkan segala sumber bergerak secara efektif.

4. Bidang usaha (line of business), Bank kurang tertarik memberikan kredit kepada usaha yang sudah jenuh. Misalnya usaha yang sudah melebihi kebutuhan.

5. Rekening, perhatian bank ditujukan pada perputaran keuangan yang disalurkan dalam rekening nasabah selama ini, yaitu mutasi penarikan dan penyetoran.

6. Pergaulan sosial, Bank menganggap hal ini penting untuk mengukur tingkat hubungan sipemohon bermasyarakat.

7. Permintaan Produksi, Bank akan meneliti apakah permintaan akan barang atau jasa yang dijual sipemohon meningkat.

8. Persaingan, Bank juga akan menyelidiki saingan dalam pemasaran barang-barang sipemohon kredit.

\section{Kredit Bermasalah.}

Dalam kasus kredit bermasalah, debitur mengingkari janji mereka membayar bunga dan atau kredit induk yang telah jatuh tempo, sehingga terjadi keterlambatan pembayaran atau sama sekali tidak ada pembayaran.

Dalam dunia perbankan internasional, kredit dapat dikategorikan dalam kredit bermasalah bilamana: 
1. Terjadinya keterlambatan pembayaran bunga dan atau kredit induk lebih dari 90 hari semenjak tanggal jatuh tempo.

2. Tidak dilunasi sama sekali.

3. diperlukan negosiasi kembali atas syarat pembayaran kembali kredit dan bunga yang tercantum dalam perjanjian kredit.

Dalam ketentuan perbankan, Bank Indonesia membagi kredit bermasalah di Indonesia menjadi tiga golongan, yaitu kredit kurang lancar, kredit-kredit diragukan dan kredit macet. (Siswanto Sutojo, $1997: 12$ ).

\section{Upaya Penanganan Kredit Bermasalah.}

Upaya penyelamatan kredit dilakukan oleh bank apabila mereka melihat masih ada kemungkinan memperbaiki kondisi operasi usaha dan keuangan debitur serta masih menguasai harta jaminan yang berharga. Upaya penyelamatan itu perlu direncanakan dengan baik agar diharapkan berhasil. Sasaran jangka pendek dan menengah yang ingin dijangkau dengan upaya penyelamatan kredit diformulasikan dengan baik. Strategi untuk mencapai sasaran perlu disusun secara profesional. Kredit bermasalah menuntut upaya penanganan yang serius dan cepat, oleh karena itu setelah rencana dan strategi penyelamatan tersusun rapi, bank harus segera melakukan kontak dengan debitur.

Untuk memperoleh keyakinan bahwa operasi bisnis dan kondisi keuangan perusahaan masih dapat diperbaiki, perlu diadakan studi khusus guna menilai prospek masa depan mereka. Bila mana perlu, bank dan debitur mengundang perusahaan konsultan atau pakar yang telah berpengalaman dalam penanganan kasus kredit bermasalah, untuk membantu mereka melakukan studi itu. Upaya penyelamatan kredit dapat dilakukan dengan tiga macam cara, yaitu:

a. Penjadwalan kembali pelunasan kredit.

b. Penataan kembali persyaratan kredit.

c. Re organisasi dan rekapitulasi.

Cara penyelamatan manapun yang dipilih, rencana penyelamatan tadi harus dituangkan dalam satu dokumen tertulis yang disetujui oleh pimpinan bank. Selanjutnya upaya penyelamatan tersebut harus dimonitor secara ketat. Laporan tertulis tentang perkembangan hasil yang dapat dicapai secara tepat disampaikan oleh para peleksana upaya penyelamatan kepada pimpinan bank. Dengan demikian, apabila pimpinan bank mengetahui bahwa hasil yang dicapai ternyata jauh dari sasaran yang telah direncanakan, dapat diadakan koreksi seperlunya.

\section{Bank}

\section{Pengertian Bank.}

Pengertian bank dalam sistem lembaga keuangan adalah merupakan lembaga mediator antara pihak yang mengalami kekurangan dana dengan pihak yang kelebihan dana.

Sedangkan definisi bank menurut Undang-undang Nomor 7 Tahun 1992 tentang perbankan sebagaimana telah diubah dengan Undang-undang Nomor 10 Tahun 1998, adalah sebagai berikut:

"Bank adalah badan usaha yang menghimpun dana dari masyarakat dalam bentuk simpanan, dan menyalurkannya kepada masyarakat dalam bentuk kredit dan atau bentukbentuk lainnya dalam rangka meningkatkan taraf hidup rakyat banyak”. 


\section{Usaha Bank}

Usaha bank secara sederhana dapat didefinisikan sebagai kegiatan menghimpun dana dari masyarakat dan menyalurkanya kembali kepada masyarakat. Namun demikian, secara lebih rinci dan spesifik kegiatan usaha bank diatur dalam Undang-undang Nomor 7 Tahun 1992 tentang perbankan Jo.

Undang-undang Nomor 10 Tahun 1998, baik untuk bank umum maupun Bank Perkriditan Rakyat.

1). Usaha Bank Umum

a. Kegiatan-kegiatan usaha yang dapat dilakukan oleh Bank Umum yaitu:

- Menghimpun dana dari masyarakat dalam bentuk simpanan berupa giro, deposito berjangka, sertifikat depiosito, tabungan dan atau bentuk lain yang dipersamakan dengan itu.

- Memberikan kredit.

- Menerbitkan surat pengakuan hutang.

- Membeli, menjual atau menjamin atas resiko sendiri maupun untuk kepentingan dan atas perintah nasabahnya, yang meliputi surat wesel, surat pengakuan hutang, kertas perbendaharaan negara dan surat jaminan pemerintah, Sertifikat Bank Indonesia, obligasi, surat dagang waktu sampai dengan 1 tahun, dan instrumen surat berharga lain berjangka waktu sampai dengan 1 tahun.

- Memindahkan uang, baik untuk kepentingan sendiri maupun untuk kepentingan nasabah.

- Menempatkan dana pada, meminjamkan dana dari, atau meminjamkan dana kepada bank lain, baik dengan menggunakan surat, sarana telekomunikasi maupun wesel unjuk, cek atau sarana lainnya.

- Menerima pembayaran dari tagihan atas surat berharga dan melakukan perhitungan dengan atau antara pihak ketiga.

- Menyediakan tempat untuk menyimpan barang atau surat berharga.

- Melakukan kegiatan penitipan untuk kepentingan pihak lain berdasarkan suatu kontrak.

- Melakukan penempatan dana dari nasabah kepada nasabah lainnya dalam bentuk surat berharga yang tidak tercatat dibursa efek.

- Melakukan kegiatan anjak piutang, usaha kartu kredit dan kegiatan wali amanat.

- Menyediakan pembiayaan dan atau melakukan kegiatan lain berdasarkan prinsip syariah, sesuai dengan ketentuan yang ditetapkan oleh Bank Indonesi.

- Melakukan kegiatan lain yang lazim dilakukan oleh bank sepanjang tidak bertentangan dengan undang-undang dan peraturan yang berlaku.

b. Selain melakukan kegiatan usaha sebagaimana yang diuraikan diatas, Bank Umum dapat pula melakukan hal-hal sebagai berikut:

- Melakukan kegiatan dalam valuta asing dengan memenuhi ketentuan yang ditetapkan Bank Indonesia.

- Melakukan kegiatan penyertaan modal pada bank atau perusahaan lain dibidang keuangan, seperti sewa guna usaha, modal ventura, perusahaan efek, asuransi, serta lembaga kliring/ penyelesaian dan penyimpanan dengan memenuhi yang ditetapkan oleh bank indonesi.

- Melakukan penyertaan modal sementara untuk mengatasi akibat kegagalan kredit atau kegagalan pembiayaan berdasarkan prinsip syariah, dengan syarat 
harus menarik kembali penyertaannya, dengan memenuhi ketentuan yang ditetapkan Bank Indonesia.

- Bertindak sebagai pendiri dana pensiun dan pengurus dana pensiun sesuai dengan ketentuan dalam peraturan perundangan dana pensiun yang berlaku.

a. Dalam melaksanakan kegiatan usahanya, Bank Umum dilarang untuk melakukan hal-hal sebagai berikut:

- Melakukan penyertaan modal, kecuali yang telah diperkenankan sebagaimana diuraikan diatas.

- Melakukan usaha perasuransian.

- Melakukan usaha lain diluar kegiatan usaha sebagaimana dimaksud dalam uraian diatas.

2). Usaha Bank Perkreditan Rakyat.

a. Usaha-usaha yang diperkenankan bagi Bank Perkreditan Rakyat adalah sebagai berikut yaitu:

- Menghimpun dana dari masyarakat dalam bentuk simpanan berupa deposito berjangka, tabungan dan atau bentuk lainya yang dipersamakan dengan itu.

- Memberi kredit.

- Menyediakan pembiayaan dan penempatan dana berdasarkan prinsip syariah, sesuai dengan ketentuan yang ditetapkan oleh Bank Indonesia.

b. Bank Perkreditan Rakyat dilarang untuk melakukan kegiatan sebagai berikut:

- Menerima simpanan berupa giro dan ikut serta dalam lalu lintas pembayaran.

- Melakukan kegiatan usaha dalam valuta asing.

- Melakukan penyertaan modal.

- Melakukan usaha perasuransian.

- Melakukan usaha lain diluar kegiatan usaha sebagaimana diuraikan diatas.

\section{Peranan Pengendalian Intern Terhadap Pemberian Kredit}

Terdapat dua fungsi pokok bank yaitu fungsi penyimpanan dana masyarakat yang disebut operasi kredit pasif dan fungsi penyaluran kredit ke masyarakat disebut operasi kredit aktif. Oleh karena kegiatan pemberian kredit merupakan sumber utama pendapatan bank dan dalam menjalankan kegiatan tersebut bank akan menghadapi resiko, maka untuk itu diperlukan suatu kebijaksanaan yang memadai agar kegiatan perkreditan bank dapat dikendalikan.

Untuk menunjang keberhasilan pengawasan kredit, bank harus mempunyai sistem pengendalian intern yang cukup memadai. Sistem pengendalian intern kredit tersebut harus dapat diterapkan dalam semua tahap proses penyaluran kredit, mulai dari saat permintaan kredit diajukan oleh debitur sampai saat kredit dibayar lunas. Sistem pengendalian intern harus memberikan peluang kepada bank untuk melakukan pengawasan ganda, terutama pada tahap-tahap penyaluran kredit yang mengandung kerawanan penyalahgunaan oleh semua pihak yang terkait dalam pemberian kredit atau dapat merugikan bank. Sistem pengendalian intern juga harus memberikan kemungkinan bank untuk mendeteksi sedini mungkin terjadinya pelanggaran atas kebijaksanaan pokok penyaluran kredit dan prosedur pelaksanaan pemberian kredit. 
Berdasarkan uraian diatas, maka dapat dibuat paradigma penelitian, sbb:

Gambar 1. Paradigma Penelitian

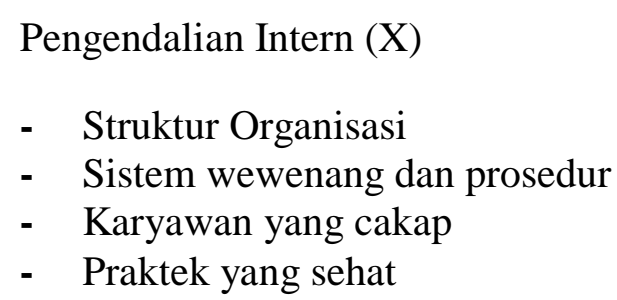

\section{Hipotesis}

Berdasarkan kerangka pemikiran maka dirumuskan hipotesis:

"Peranan pengendalian intern perkreditan (Struktur Organisasi, Sistem Wewenang dan Prosedur Pencatatan, Karyawan yang cakap dan Praktek yang sehat) berpengaruh secara signifikan terhadap kredit bermasalah"

Hipotesis Statistik :

Ho $: \rho=0$ berarti : Tidak ada pengaruh yang signifikan antara pengendalian intern perkreditan terhadap kredit bermasalah.

Ho: $\rho \neq 0$ berarti : Terdapat pengaruh yang signifikan antara pengendalian intern perkreditan terhadap kredit bermasalah.

\section{METODOLOGI PENELITIAN}

\section{Definisi Operasional Penelitian}

Jenis penelitian ini dalam bentuk penelitian deskriptip dan asosiatif.

Penelitian deskriftip dilakukan untuk mendapatkan gambaran tentang variabel penelitian yang digunakan, sedangkan penelitian asosiatif digunakan untuk menguji hubungan atau pengaruh antara pengendalian intern perkreditan terhadap tingkat tunggakan kredit dengan menggunakan uji statistik.

\section{Variabel Penelitian}

a. Variabel bebas $(\mathbf{X})$ yaitu pengendalian intern dengan indikator:

Struktur organisasi. Sistem prosedur dan wewenang, karyawan yang cakap dan praktek yang sehat.

b. Variabel terikat (Y) yaitu: Tingkat tunggakan Kredit dengan indikator:

Kredit dalam pengawasan khusus, kredit kurang lancar, kredit diragukan dan kredit macet. 
Tabel 3.1 Operasionalisasi Variabel

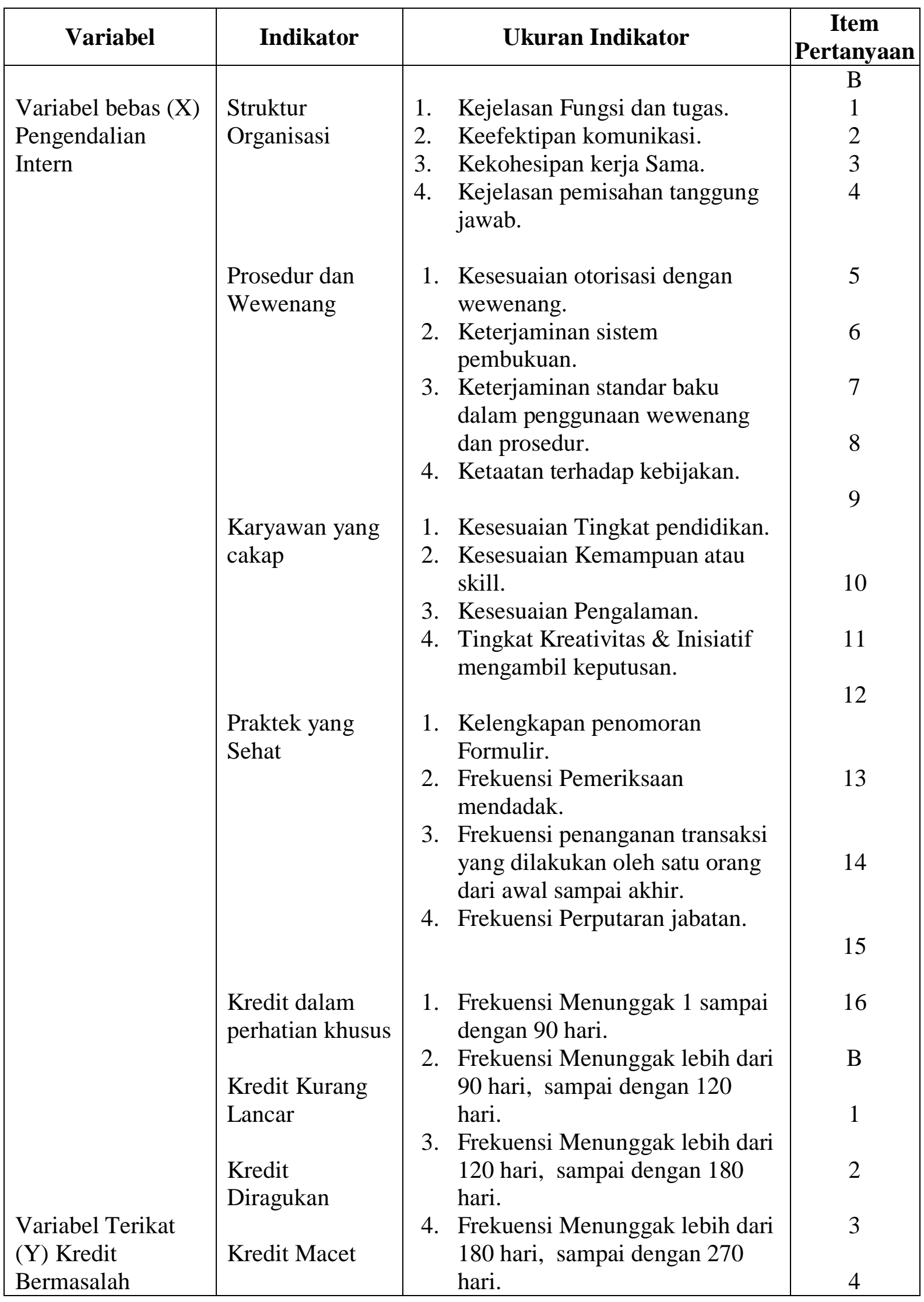




\section{Pengukuran Variabel:}

Variabel diukur dengan cara memberi skor atas setiap jawaban responden Pada kuesioner yang diberikan. Setiap indikator, disediakan empat pertanyaan atau pernyataan. Kriteria skor sbb:

Untuk variabel $\mathrm{X}$

- Jawaban a. diberi skor 5

- Jawaban b. diberi skor 4

- Jawaban c. diberi skor 3

- Jawaban d. diberi skor 2

- Jawaban e. diberi skor 1

Untuk variabel Y

- Jawaban sangat jarang diberi skor 5

- Jawaban jarang diberi skor 4

- Jawaban cukup sering diberi skor 3

- Jawaban sering diberi skor 2

- Jawaban sangat sering diberi skor 1

Dalam pengukuran variabel diatas digunakan skala Likert

\section{Sumber Data}

Data Primer diperoleh dengan cara melakukan penyebaran kuesioner dan observasi langsung serta wawancara yang dilakukan terhadap manajer dan staf yang mengetahui tentang jumlah perkembangan kredit bermasalah.

Data sekunder adalah data yang diperoleh dari dokumentasi bank sebagai objek yaitu mengenai data kredit yang disalurkan ke masyarakat dan besarnya angsuran yang menunggak.

\section{Tehnik Pengumpulan Data}

\section{A. Penelitian Kepustakaan}

Penelitian ini dilakukan dengan cara membaca literatur dan bahan bacaan lainnya guna memperoleh teori sebagai dasar untuk pemecahan masalah yang dikaji.

\section{B. Penelitian Lapangan}

Penelitian ini dilakukan dengan cara mengamati langsung kegiatan objek penelitian, yang dilakukan dengan observasi, wawancara, dokumentasi dan menyebar kuesioner.

\section{Populasi dan Sampel}

Populasi, yang menjadi populasi dalam penelitian ini adalah seluruh karyawan PT. BRI (Persero) Cabang Teluk Betung yang berjumlah 157 orang.

Sampel, Menurut Arikunto (2004 : 102), sampel adalah sebagian atau wakil dari populasi yang diteliti, bila subjeknya kurang dari 100, lebih baik diambil semua, selanjutnya bila subjeknya lebih dari 100 dapat diambil $10-15 \%$ atau $20-25 \%$, atau lebih tergantung kemampuan. Berdasarkan pendapat tersebut maka dalam penelitian ini, peneliti mengambil sampel $25 \%$ yaitu sebanyak 39 orang sebagai responden. Dalam menentukan sampel penulis menggunakan tehnik Disproportionate stratified random sampling, yaitu menggunakan strata namun tidak proporsional (Sugiono : 2004 : 76). Dalam penelitian ini yang menjadi sampel adalah pimpinan dan karyawan yang mengetahui tentang penerapan pengendalian intern dan yang mengelola kredit serta yang mengetahui tentang kredit bermasalah, yang terdiri dari 
Asisten Manager Bisnis Mikro 1 orang, Penilik 2 orang, Kepala Unit 12 orang, Account Officer (Mantri) 12 orang, dan Deskmen 12 orang.

\section{Tehnik Analisis Data}

\section{Analisa Kualitatif}

Data penelitian yang dikumpulkan dianalisis dengan pendekatan deskriptip kualitatif untuk masing-masing indikator variabel dengan menggunakan rumus Interval sebagai berikut:

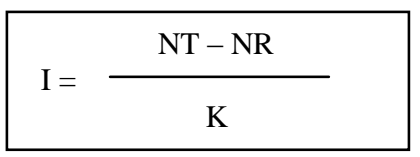

Keterangan :

I = Interval

NT = Jumlah skor tertinggi

$\mathrm{NR}=$ Jumlah skor terendah

$\mathrm{K}$ = Banyaknya kategori

\section{Analisa Kuantitatif}

Untuk mengetahui koefisien korelasi digunakan rumus korelasi product Moment sebagai berikut (Sugiyono 2005 : 213).

$$
\mathrm{I}=\frac{\mathrm{n}\left(\sum \mathrm{XY}\right)-\left(\sum \mathrm{X} \sum \mathrm{Y}\right)}{\sqrt{\left[\mathrm{n} \sum^{2}-(\mathrm{X})^{2}\right]\left[\mathrm{n} \sum \mathrm{Y}^{2}-\left(\sum \mathrm{Y}\right)^{2}\right]}}
$$

Keterangan :

$\mathrm{X}=$ Skor dari pernyataan

$\mathrm{Y}=$ Skor total pernyataan

$\mathrm{N}=$ Jumlah responden

Perhitungan dalam rangka mencari koefisien korelasi memamfaatkan program aplikasi komputer exel dan SPSS.

Selanjutnya untuk mengetahui tingkat kekuatan hubungan, koefisien korelasi yang diperoleh di konsultasikan dengan tabel pedoman interpretasi koefisien korelasi sebagai berikut:

Tabel 3.2 Pedoman konsultasi koefisien korelasi

\begin{tabular}{|c|c|l|}
\hline No & Interval Koefisien & \multicolumn{1}{|c|}{ Tingkat Hubungan } \\
\hline 1 & $0,000-0,199$ & Sangat Lemah \\
\hline 2 & $0,200-0,399$ & Lemah \\
\hline 3 & $0,400-0,599$ & Sedang \\
\hline 4 & $0,600-0,799$ & Kuat \\
\hline 5 & $0,800-1,000$ & Sangat Kuat \\
\hline
\end{tabular}

Sumber Sugiyono $(2005: 216)$

Untuk mengetahui besarnya pengaruh variabel Peranan Pengendalian Intern (X) terhadap variabel Tingkat Tunggakan Kredit (Y), digunakan rumus Koefisien Penentu (KP) sebagai berikut : (J. Supranto 1999 : 185) 


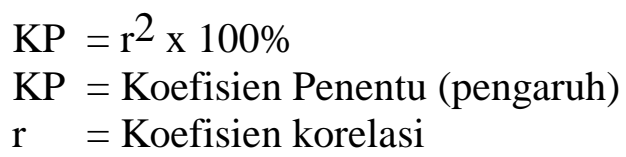

Untuk mengetahui besarnya pengaruh variabel peranan pengendalian intern dalam sistem dan prosedur pembelian kredit (X) terhadap Tingkat tunggakan kredit (Y) digunakan rumus koefisien korelasi dengan menggunakan koefisien korelasi t sbb: (Nur Indriantoro 1999 : 209).

\begin{tabular}{rr}
$\mathrm{t}=\mathrm{r}$ & $\sqrt{\mathrm{n}-2}$ \\
& $1-\mathrm{r}^{2}$ \\
\hline
\end{tabular}

$\mathrm{n} \quad=$ Jumlah sampel

$\mathrm{r} \quad=$ Koefisien korelasi

Untuk menguji signifikansi, koefisien korelasi menggunakan distribusi t yang diperoleh dibandingkan dengan tabel distribusi $t$, dengan kriteria jiak $t$ hitung $>t$ tabel, maka antar variabel memiliki hubungan yang kuat. Dalam pengujiannya digunakan tingkat signifikansi $\alpha=0,05$ atau $95 \%$.

\section{PEMBAHASAN}

\section{Analisa Kualitatif}

Berdasarkan skor dari jawaban responden pada lampiran 1, diketahui bahwa untuk masing-masing indikator pengendalian intern dan kredit bermasalah skor tertinggi adalah 20 dan skor terndah adalah 4.

\section{Analisis Pengendalian Intern}

Dengan menggunakan rumus interval, yaitu skor tertinggi dikurangi skor terendah, dan dibagi dengan banyaknya karegori yang ditentukan yaitu 5 (lima), maka diperoleh kategori untuk masing-masing indicator sebagai berikut:

Berdasarkan banyaknya pertanyaan/pernyataan, didapat nilai tertinggi 20 dan terendah 4, maka didapat interval 3,2 dibulatkan menjadi 3.

Kategori untuk masing-masing indikator sebagai berikut:

- Dinyatakan sangat jelas, sangat menjamin, sangat cakap, sangat sehat apabila berada pada interval : $20-23$

- $\quad$ Dinyatakan jelas, menjamin, cakap, sehat, apabila berada pada interval 16 - 19

- Dinyatakan cukup jelas, cukup menjamin, cukup cakap, cukup sehat, apabila berada pada interval $12-15$.

- $\quad$ Dinyatakan kurang jelas, kurang menjamin, kurang cakap, kurang sehat, apabila berada pada interval $8-11$

- Dinyatakan tidak jelas, tidak menjamin, tidak cakap, tidak sehat, apabila berada pada interval $4-7$. 
Untuk lebih jelasnya dapat dilihat pada tabel berikut:

\begin{tabular}{|l|c|l|l|}
\hline $\begin{array}{l}\text { Cukup } \\
\text { Jelas }\end{array}$ & $12-15$ & 22 & 56 \\
\hline $\begin{array}{l}\text { Kurang } \\
\text { Jelas }\end{array}$ & $8-11$ & 16 & 41 \\
\hline $\begin{array}{l}\text { Tidak } \\
\text { Jelas }\end{array}$ & $4-7$ & 0 & 0 \\
\hline J u m la h & & 39 & 100 \\
\hline
\end{tabular}

Sumber : data di olah th 2006

Berdasarkan data diatas diperoleh keadaan sebagai berikut: Dari 39 responden, yang menyatakan struktur organisasi jelas 1 orang (1\%), cukup jelas 22 orang (56\%) dan kurang jelas 16 orang $(41 \%)$. Dengan demikian untuk indikator struktur organisasi dapat dikatakan cukup jelas yang berarti apabila fungsi permohonan kredit, analis kredit dan otorisasi kredit dilakukan oleh 1 (satu) orang, maka hasilnya cenderung tidak baik

Untuk indikator Wewenang dan Prosedur pembukuan, dari 39 orang responden yang menyatakan menjamin sebanyak 18 orang (46\%), cukup menjamin 20 orang (51\%), dan kuramng menjamin 1 orang $(3 \%)$.

Dengan demikian untuk indikator wewenang dan prosedur pembukuan dapat dikatakan cukup menjamin yang berarti apabila kebijakan-kebijakan, prosedur-prosedur dan wewewnang tidak ditaati maka hasilnya tidak dapat menjamin.

Untuk indikator karyawan yang cakap, dari 39 orang responden yang menyatakan cakap 1 orang ( $3 \%$ ), cukup cakap 20 orang (51\%), kurang cakap 18 orang (46\%) sebanyak 18 orang (46\%), cukup menjamin 20 orang (51\%), dan kuramng menjamin 1 orang (3\%).

Dengan demikian untuk indicator wewenang dan prosedur pembukuan dapat dikatakan cukup menjamin yang berarti apabila fungsi permohonan kredit, analis kredit dan otorisasi kredit dilakukan oleh 1 orang, maka hasilnya cenderung tidak baik atau tidak Menjamin

Untuk indikator Wewenang dan Prosedur pembukuan, dari 39 orang responden yang menyatakan menjamin sebanyak 18 orang (46\%), cukup menjamin 20 orang (51\%), dan kuramng menjamin 1 orang (3\%).

Dengan demikian untuk indicator wewenang dan prosedur pembukuan dapat dikatakan cukup menjamin yang berarti apabila fungsi permohonan kredit, analis kredit dan otorisasi kredit dilakukan oleh 1 orang, maka hasilnya cenderung tidak baik atau tidak menjamin.

\section{Analisa Variabel Kredit Bermasalah}

Untuk bermasalah nilai tertinggi 20 dan nilai terendah 4, interval 3,2 dibulatkan 3.

- Dinyatakan sangat jarang apabila berada pada interval 18-19

- Dinyatakan jarang apabila berada pada interval 16-17

- Dinyatakan cukup sering apabila berada pada interval 14-15

- Dinyatakan sering apabila berada pada interval 12-13

- Dinyatakan sangat sering apabila berada pada interval 10-11 
Untuk lebih jelasnya dapat dilihat pada tabel berikut:

Tabel 4.26. Kategori jawaban responden untuk variabel Kredit Bermasalah

\begin{tabular}{|l|c|c|c|}
\hline \multicolumn{1}{|c|}{ Kategori } & Interval & Frekuensi & Persentase (\%) \\
\hline Sangat jarang & $20-23$ & 0 & 0 \\
\hline Jarang & $16-19$ & 0 & 0 \\
\hline Cukup sering & $12-15$ & 21 & 54 \\
\hline Sering & $8-11$ & 18 & 46 \\
\hline Sangat sering & $4-7$ & 0 & 0 \\
\hline Jumlah & & 39 & 100 \\
\hline
\end{tabular}

Sumber: Data diolah 2006

Berdasarkan data diatas diperoleh keadaan sebagai berikut:

Dari 39 orang respondet, yang menyatakan tinggkat kredit bermasalah pada PT. BRI, Cabang Teluk Betung cukup sering sebanyak 21 orang atau 54\% dan sering 18 atau 46\%, dengan demikian tingkat kredit bermasalah pada PT. BRI, Cabang Teluk Betung, dapat dinyatakan cukup sering

\section{Analisis Kuantitatif}

Analisis Kuantitatif dilakukan untuk mengetahui koefisien korelasi antar variabel. Analisisa ini menggunakan Rumus Korelasi.

\begin{tabular}{|l|l|c|c|}
\hline $\begin{array}{l}\text { No } \\
\cdot\end{array}$ & \multicolumn{1}{|c|}{ KORELASI } & Koefisien & $\begin{array}{c}\text { Koefisien } \\
\text { Penentu (\%) }\end{array}$ \\
\hline 1. & Indikator Struktur Organisasi dengan Kredit Bermasalah & 0,654 & 42,77 \\
\hline 2. & $\begin{array}{l}\text { Indikator Sistem Wewenang dan Prosedur Pencatatan } \\
\text { dengan Kredit Bermasalah }\end{array}$ & 0,482 & 23,23 \\
\hline 3. & $\begin{array}{l}\text { Indikator Karyawan yang Cakap dengan Kredit } \\
\text { Bermasalah }\end{array}$ & 0.716 & 51,27 \\
\hline 4. & $\begin{array}{l}\text { Indikator Praktek Yang Sehat dengan Kredit } \\
\text { Bermasalah }\end{array}$ & 0,605 & 36,60 \\
\hline 5. & \begin{tabular}{l} 
Variabel Pengendalian Intern dengan Kredit Bermasalah \\
\hline
\end{tabular} & 0,798 & 63,60 \\
\hline
\end{tabular}

Dari tabel 4.27. maka dapat diketahui besarnya koefisien korelasi masing-masing indikator Pengendalian Intern Perkreditan (X) dengan Kredit Bermasalah (Y), dengan penjelasan sebagai berikut:

1. Koefisien Korelasi untuk indikator struktur organisasi dengan kredit bermasalah yaitu 0,654 bertanda positif. Hal ini berarti bahwa terdapat hubungan positif antara indikator struktur organisasi dengan kredit bermasalah pada PT. BRI-unit Cabang Teluk Betung. Besarnya koefisien korelasi 0,654 jika dikonsultasikan dengan tabel pedoman konsultasi Koefisien Korelasi pada (halaman 34) berada pada interval 0,600-0,799. yang berarti menunjukkan tingkat hubungan yang kuat, Sedangkan besarnya koefisien Penentu yaitu r2 x $100 \%=42,77 \%$ yang berarti pengaruh unsur struktur organisasi terhadap kredit bermasalah sebesar $42,77 \%$.

2. Koefisien Korelasi untuk indikator sistem wewenang dan prosedur pencatatan dengan kredit bermasalah yaitu 0,482 bertanta positif. Hal ini berarti bahwa terdapat hubungan 
positif antara indikator sistem wewenang dan prosesdur pencatatan dengan kredit bermasalah pada PT. BRI-unit Cabang Teluk Betung. Besarnya koefisien korelasi 0,482 jika dikonsultasikan dengan tabel pedoman konsultasi koefisien Korelasi pada (halaman 34) berada pada interval 0,400 - 0,599. yang berarti menunjukkan tingkat hubungan yang sedang. Sedangkan besarnya koefisien Penentu yaitu r2 x $100 \%=23,23 \%$, yang berarti pengaruh unsur sistem wewenang dan prosedur pencatatan terhadap kredit bermasalah sebesar 23,23\%.

3. Koefisien Korelasi untuk indikator karyawan yang cakap dengan kredit bermasalah yaitu 0,716 bertanda positif. Hal ini berarti bahwa terdapat hubungan positif antara indikator karyawan yang cakap dengan kredit bermasalah pada PT. BRI-unit Cabang Teluk Betung. Besarnya koefisien korelasi 0,716 jika dikonsultasikan dengan tabel pedoman konsultasi Koefisien Korelasi pada (halaman 34) berada pada interval 0,600 - 0,799. yang berarti menunjukkan tingkat hubungan yang kuat. Sedangkan besarnya Koefisien Penentu yaitu r2 x $100 \%=51,27 \%$, yang berarti pengaruh unsur karyawan yang cakap terhadap kredit bermasalah sebesar $51,27 \%$.

4. Koefisien Korelasi untuk indikator praktek yang sehat dengan kredit bermasalah yaitu 0,605 bertanda positif. Hal ini berarti bahwa terdapat hubungan positif antara indikator sistem wewenang dan prosedur pencatatan dengan kredit bermasalah pada PT. BRI-unit Cabang Teluk Betung. Besarnya kofesien korelasi 0,605 jika dikonsultasikan dengan tabel pedoman konsultasi Koefisien Korelasi pada (halaman 34) berada pada interval 0,600 - 0,799. yang berarti menunjukkan tingkat hubungan yang kuat. Sedangkan besarnya Koefisien Penentu yaitu r2 x 100\%=36,60\%, yang berarti pengaruh unsur praktek yang sehat terhadap kredit bermasalah sebesar 36,60\%.

5. Koefiesien Korelasi untuk variabel Pengendalian Intern (X) dengan kredit bermasalah (Y) yaitu $\mathrm{rXY}=0,798$ bertanda positif. Hal ini berarti bahwa terdapat hubungan positif antara variabel pengendalian intern dengan kredit bermasalah pada PT. BRI-unit Cabang Teluk Betung. Besarnya koefisien korelasi 0,798 jika dikonsultasikan dengan tabel pedoman konsultasi Koefisien Korelasi pada (halaman 29) berada pada interval 0,600 0,799. yang berarti menunjukkan tingkat hubungan yang kuat. Sedangkan besarnya Koefisien Penentu yaitu r2 x 100\%=63,60\%, Hal ini berarti Pengendalian Intern perkreditan mempengaruhi Kredit Bermasalah sebesar 63,60\%, dengan asumsi sisanya dipengaruhi oleh faktor lain.

Berdasarkan pendapat Sugiono (2004:217), untuk mengetahui signifikansi atau apakah hasil korelasi dapat digeneralisasikan, dapat dilakukan dengan membandingkan koefisien $\mathrm{t}$ yang diperoleh ( $\mathrm{t}$ hitung) dengan ( $\mathrm{t}$ tabel) dengan kriteria hubungan atau korelasi signifikan jika hubungan atau korelasi signifikan $t$ hitung $>\mathrm{t}$ tabel. Ternyata pada tarap signifikansi 5\% atau Tingkat Kepercayaan 95\% untuk jumlah $\mathrm{n}=39$ dengan dk (derajat kepercayaan 37) yang mendekati dk 40, maka diperoleh nilai 8,041 > 2,021, yang berarti tolak Ho terima Ha.

Dengan demikian, hipotesis yang diajukan dalam penelitian ini yang menyatakan terdapat Pengaruh Yang Signifikan antara Pengendalian Intern Perkreditan Terhadap Kredit Bermasalah pada PT. BRI-unit Cabang Teluk Betung, dapat diterima. 


\section{KESIMPULAN DAN IMPLIKASI}

\section{Kesimpulan}

Berdasarkan pembahasan pada Bab sebelumnya maka dapat disimpulkan:

1. Variabel Pengendalian Intern (X) pada PT. Bank Rakyat Indonesia (BRI) Cabang Teluk Betung secara umum dinilai cukup memadai oleh responden penelitian ini, yang ditunjukkan dengan hasil analisa setiap unsur pengendalian intern sebagai berikut:

- Hasil analisa kejelasan pembagian tugas, fungsi dan tanggung jawab dalam struktur organisasi menunjukkan 3\% menyatakan jelas, 56\% menyatakan cukup jelas, dan $41 \%$ menyatakan kurang jelas.

- Hasil analisa dari keterjaminan pembukuan yang didukung dengan kejelasan wewenang dan prosedur yang sesuai menunjukkan $46 \%$ menjamin, $51 \%$ menyatakan cukup menjamin dan 3\% kurang cakap.

- Hasil analisa kecakapan karyawan menunjukkan 3\% cakap, 51\% menyatakan cukup cakap, dan $46 \%$ kurang cakap.

- Hasil analisa dari praktek yang sehat menunjukkan $41 \%$ sehat, $49 \%$ cukup sehat dan $10 \%$ menyatakan kurang sehat.

2. Variabel Kredit Bermasalah (Y) pada PT. BRI-unit Cabang Teluk Betung secara umum dinilai Cukup Sering oleh responden penelitian ini, yang ditunjukkan dengan hasil analisa sebanyak 54\% responden menjawab cukup sering, dan $46 \%$ menjawab sering terjadi.

3. Berdasarkan analisa kuantitatif terdapat pengaruh yang signifikan antara variabel Pengendalian Intern Perkreditan (X) terhadap variabel Kredit Bermasalah (Y) pada PT. BRI-unit Cabang Teluk Betung yang ditunjukkan dengan koefisien korelasi sebesar 0,798 , besarnya pengaruh antara variabel bebas dan variabel terikat sebesar $63,60 \%$. Untuk menguji signifikansinya digunakan uji $\mathrm{t}$ dan didapat $\mathrm{t}$ hitung $>\mathrm{t}$ tabel dengan nilai $8,041>2,021$, yang berarti tolak Ho terima Ha.

\section{Implikasi}

Mengingat adanya pengaruh yang signifikan antara variabel Pengendalian Intern Perkreditan terhadap Kredit Bermasalah pada PT. Bank Rakyat Indonesia-unit Cabang Teluk Betung, maka hal yang perlu mendapat perhatian utama manajemen adalah meningkatkan pelaksanaan pengendalian intern agar dapat terwujud pengendalian intern yang dapat lebih menjamin keamanan harta kekayaan perusahaan, dengan cara meningkatkan efektifitas masing-masing indikator pengendalian intern yang terdiri dari:

1. Untuk dapat meningkatkan efektifitas indikator struktur organisasi manajemen dapat melakukan:

- Mempertegas tugas masing-masing bagian pengelola kredit, mulai dari permohonan kredit yang diterima sampai dengan pengembaliannya.

- Memperjelas tanggung jawab bagian-bagian yang terlibat dalam struktur organisasi pengelolaan kredit.

2. Untuk dapat meningkatkan kecakapan pegawai dalam mengelola kredit dan menangani kredit bermasalah, manajemen dapat melakukannya dengan:

- Dalam penerimaan pegawai, latar belakang pendidikan calon pegawai disesuaikan dengan formasi yang tersedia.

- Penempatan pegawai pengelola kredit dan penanganan kredit bermasalah, disamping harus sesuai dengan latar belakang pendidikan kemampuan dan skill yang dimiliki, diutamakan pada pegawai yang berpengalaman. 


\section{DAFTAR PUSTAKA}

Bodnar George. H dan Willian S.Hopwood, 2000, Sistem Informasi Akuntansi Salemba Empat. Jakarta.

Dian Jung, ST,2002, Manajemen Audit Meningkatkan Efektifitas dan Efisiensi Perusahaan. Penerbit Restu Agung, Jakarta.

Fakhri Husein, Muhammad, 2002, Sistem Informasi Akuntansi, YKPN, Yogyakarta.

Gitosudarmo Indriyo, 200, Perilaku Keorganisasian, BPFE, Yogyakarta.

Indriantoro Nur dan Supomo Bambang. 1999. Metodologi Penelitian Bisnis. Edisi Pertama. BPFE Yogyakarta.

Institut Bankir Indonesia (IBI), 1999, Sistem Akuntansi Perbankan Indonesia, IBI, Jakarta. Jusuf, Amir Abadi, 1997 Auditing Pendekatan Terpadu. Edisi Indonesia BPFE Yogyakarta. Mulyadi, 2001, Sistem Akuntansi. Edisi ke 3. BPFE. Yogyakata.

2002, Auditing. Edisi 6. Salemba Empat. Jakarta.

Riduan, 2005, Skala Pengukuran Variabel Penelitian, CV. Alfabeta, Bandung.

Sugiyono, 2004, Statistik Nonparametik. Cetakan ke 4. jakarta. ALFABETA.

Siregar S, 2004, Statistik Terapan Untuk Penelitian. PT. Grasindo Jakarta.

Siswanto, Sutojo, 2000, Strategi Manajemen Kredit bank Umum. PT. Damar Mulia Pustaka Jakarta.

.........., 2000 Menangani Kredit Bermasalah. PT. Pustaka Binaman Pressindo, Jakarta.

Simorangkir OP, Lembaga Keuangan Bank \& NonBank, Ghalilia Indonesia, Bogor Selatan, 2004

Suharsimi, Arikunto, 2004, Prosedur Penelitian Edisi Revisi, PT. Bina Aksara, Jakarta.

Umar, Husein, 1997 Riset Akuntansi, PT. Gramedia Pustaka Utama, Jakarta.

Wahyudi Agus, 2005 Tata Laksana Baku Penyusunan Tesis, UBL Press, Bandar Lampung. 
Sengaja dikosongkan 